\title{
TINGKAT DAYA SAING EKONOMI DAERAH KABUPATEN JENEPONTO
}

Saparuddin $M$

Fakultas Ekonomi, Universitas Negeri Jakarta

saparuddin@feunj.ac.id

\begin{abstract}
Problems in the study that the lift is the extent to which the advantages of each economic indicator that could support the policy direction of regional economic competitiveness Jeneponto.

The research method used is descriptive analysis. By describing each economic variables. The research results are obtained is found that the competitiveness of economic variables in Jeneponto still show low levels of competitiveness in comparison with other districts in South Sulawesi province. This can be seen from almost all economic sectors in Jeneponto ratio or index of economic variables at the bottom compared to other districts in South Sulawesi province.
\end{abstract}

Key Words : Daya saing ekonomi, sektor ekonomi 


\section{PENDAHULUAN}

Tujuan penguatan daya saing daerah untuk mencapai kesejahteraan masyarakat, caranya dengan pembangunan yang berkelanjutan. Bruntland (1987) mengemukakan bahwa pembangunan berkelanjutan merupakan pembangunan yang mampu memenuhi kebutuhan manusia pada masa kini tanpa melupakan kemampuan manusia dalam memenuhi kebutuhan mereka di masa yang akan datang. Konsep pembangunan berkelanjutan ini, kini sudah menjadi tujuan dalam pembangunan dan pengembangan kota dan kabupaten di Indonesia. Dalam menciptakan kota dan kabupaten yang berkelanjutan, diperlukan lima prinsip dasar, yaitu environment (ecology), economy (employment), equity, engagement and energy (Research Triangle Institute, 1996).

Permasalahan-permasalahan substansial yang merupakan isu-isu pembangunan yang akan diselesaikan kedepan yang di hadapi oleh Kabupaten Jeneponto, antara lain :

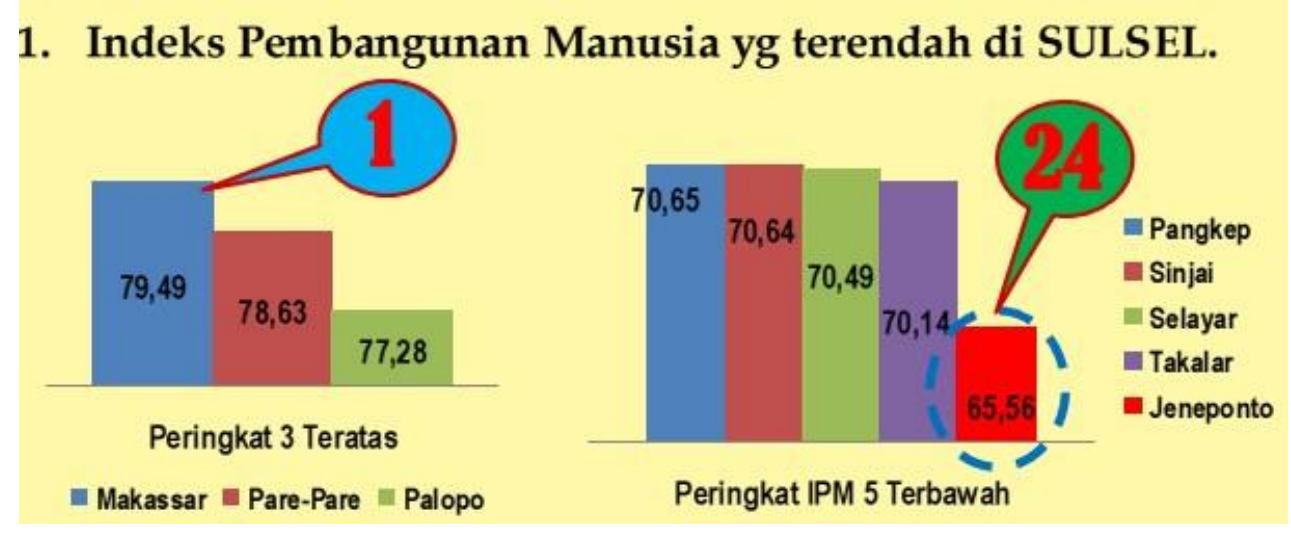

Gambar : Kondisi IPM di Sulawesi Selatan Sumber : Data Statistik IPM Sul-Sel (2014)

2. Tingkat kemiskinan masyarakat yang masih relatif tinggi

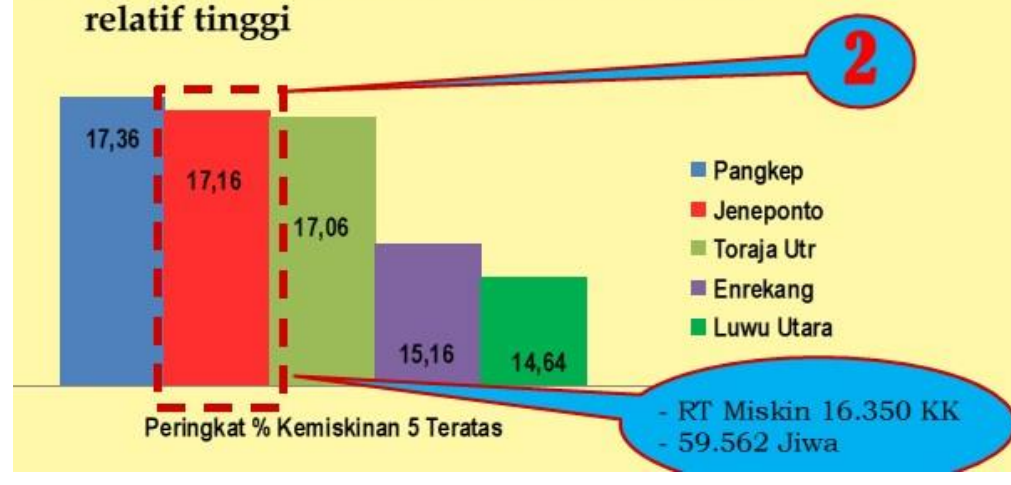

Kabupaten Jeneponto termasuk daerah daerah. yang tingkat kemiskinannya berada di urutan kedua teratas setelah Kabupaten Pangkep. Kondisi ini tentu sangat memprihatinkan sekaligus menjadi pekerjaan utama bagi pemerintah 
Tabel : Kapasistas Fiskal Daerah Sulawesi Selatan

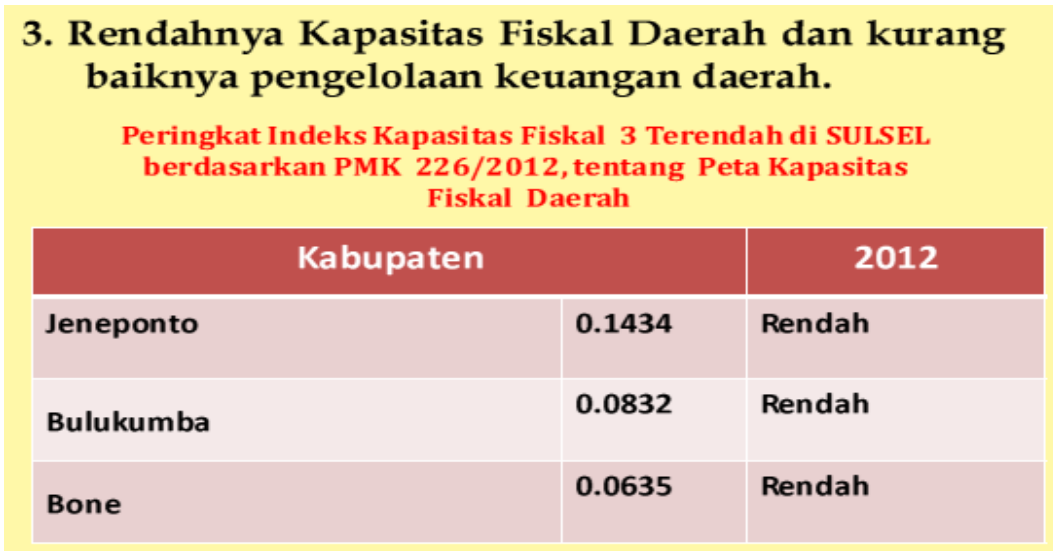

Gambar : Ketertinggalan Wilayah di Sulawesi Selatan

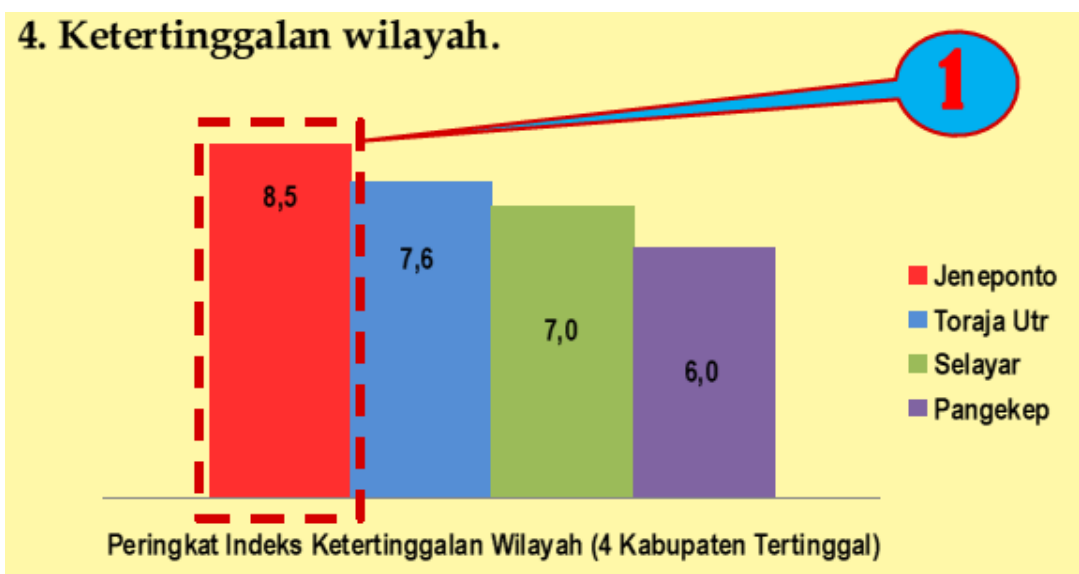

Sumber : Bappeda Provinsi Sul-Sel 2012

Tingkat daya saing (competitiveness) merupakan salah satu parameter dalam konsep kota berkelanjutan. Semakin tinggi tingkat daya saing suatu kota, maka tingkat kesejahteraan masyarakatnya pun semakin tinggi. Variabel-variabel yang diukur dalam pengukuran tingkat daya saing pada penelitian ini adalah variabel perekonomian daerah, variabel infrastruktur dan sumber daya alam, serta variabel sumber daya manusia. dan membandingkannya dengan kebijakan (fungsi kawasan strategis, struktur

\section{KAJIAN PUSTAKA}

George S. Day, dkk dalam "Assesing Advantage : A Framework for wilayah dan sektor unggulan) di Kabupaten Jeneponto.

Dalam pengembangan kawasan strategis, struktur wilayah, sektor unggulan, dan visi, serta misi; untuk melihat sejauh mana keunggulan dari masing-masing indikator ekonomi tersebut dapat mendukung arah kebijakan daya saing ekonomi daerah Kabupaten Jeneponto.

Diagnosing Competitive Superiority", bahwa keunggulan komparatif dapat 
diidentifikasi, sebagai berikut : a) Keunggulan

sumberdaya,(keterampilan/keahlian, kendali/kontrol, b) keunggulan letak, c) keunggulan kinerja hasil akhir Dalam pandangan yang lain bahwa keunggulan bisa tercipta kare na : a) tingginya kualitas kerja dan pelayan kepada publik, b) tingginya muatan teknologi, c) faktor biaya, d) tersedianya dana investasi, e) kemampuan manajemen, f) keunggulan kualitas manusia, g) kuatnya budaya dan tingginya semangat kewirausahaan, dan $h$ ) efektivitas dan efisiensi dalam penggunaan sumberdaya, serta i) kebijakan pemerintah yang kondusif (Frinces, 2013).

Konsepsi daya saing terkait dua hal penting yaitu : a) persepsi orang, dan b) adanya atribut dominan dari aspek organisasi dan produk.

Dari aspek persepsi, daya saing merupakan bentuk dari persepsi lawan atau pelanggan terhadap organisasi dan atau produk, sementara dari aspek organisasi, hal yang membantu terciptanya daya saing adalah organisasi tersebut mampu memproduksi outputnya dengan pendekatan manaejemen modern yang dilakukan secara efisien, efektif, produktif, dan optimal.

Proses penciptaan daya saing juga dapat diciptakan dari dua hal, yakni : 1) daya saing dapat diciptakan secara langsung dalam proses secara bertahap/gradual dengan waktu yang cukup panjang, 2) daya saing dapat diciptakan secara tidak langsung oleh adanya perubahan sistim, kemauan, kemampuan, dan keberanian untuk melakukan perubahan strategis.

Pengukuran tingkat daya saing ekonomi di Kabupaten Jeneponto Propinsi Sulawesi Selatan ini merupakan penelitian deskriptif kualitatif, di mana tahapan dalam penelitian ini adalah sebagai berikut.

\section{METODE PENELITIAN}

Pengukuran tingkat daya saing ekonomi di Kabupaten Jeneponto Propinsi Sulawesi Selatan ini merupakan penelitian deskriptif kualitatif, di mana tahapan dalam penelitian ini adalah sebagai berikut.

\section{Tahap Pengumpulan Data}

Pengumpulan data dilakukan dengan :

1. Survey Sekunder, untuk memperoleh data terkait nilai dari sub variable-sub variable yang telah ditetapkan

2. Survey Primer, dengan maksud untuk mengetahui pendapat para ahli atau orang yang berkompeten di bidangnya, yang nantinya akan memberikan bobot atas perbandingan relatif antar sub variabel untuk digunakan dalam AHP. Tahap Analisis

\section{PEMBAHASAN \\ Perekonomian daerah Kabupaten Jeneponto}
A. Produk Domestik Regional Bruto (PDRB)
$\begin{array}{lr}\text { Selama periode tahun 2011- } \\ 2015 \text { perekonomian } & \text { Kabupaten } \\ \text { Jeneponto } \quad \text { selalu } & \text { mengalami }\end{array}$ pertumbuhan secara fluktuatif. Untuk pertumbuhan ekonomi mempunyai
rata-rata $7,41 \%$. Di Kabupaten Jeneponto pada tahun 2011 pertumbuhanya sebesar 7,32 persen sedangkan pada tahun 2012 terjadi penurunan pertumbuhan sebesar 7,27 persen sama halnya di tahun 2013 terjadi juga penurunan pertumbuhan sebesar 6,97persen terus di tahun 2014 terjadi peningkatan sebesar 7,71 persen dan di tahun 2015 sebesar 7,80 persen. Selama lima tahun terakhir (2011-2015), total nilai tambah oleh aktifitas sektor-sektor ekonomi yang berada di wilayah kabuapten jeneponto baik atas dasar harga 
berlaku maupun atas dasar harga konstan ,secara konsisten mengalami peningkatan dari tahun ke tahun,penIngkatan yang lebih besar pada PDRB atas dasar harga berlaku di bandingkan PDRB atas dasar harga konstan yang menunjukkan adanya perubahan nilai rupiah atau terjadi inflasi. Dengan kata lain,rasio PDRB atas dasar berlaku denga PDRB atas dasar harga konstan yang semakin tinggi menunjukkan adanya peningkatan biaya produksi,meski demikian ,PDRB Kabupaten jeneponto tetap memperlihatkan pertumbuhan ekonomi yang terus konsisten meskipun di tahun 2013 pertumbuhan menurun sebesar 6,97 persen,walaupun pada tahun 2013 pertumbuhan menurun sebesar 6,97 persen, tetapi pembangunan ekonomi di kabupaten jeneponto terus membaik di lihat dari PDRB atas dasar harga berlaku dan PDRB atas dasar harga konstan tiap tahun meningkat.

Tabungan di Kabupaten Jeneponto periode 2011-2015 mengalami peningkatan penabung yaitu pada tahun 2014 sebesar Rp 98.788.700,dan terjadi penurunan pada tahun 2015 sebesar Rp 93.357.350,-. Tabungan di Jabupaten Jeneponto melalui kantor pos pada tahun 2011 sebesar Rp 49.925.000,- terjadi peningkatan tabungan pada tahun 2012 sebesar Rp 51.219.000,- sama halnya dengan tahun 2013 terjadi peningkatan tabungan drastis sebesar Rp 87.926.000 di mana pada tahun 2014 terjadi peningkatan tabungan lagi sebesar Rp 98.788.700,- dan di tahun 2015 terjadi penurunan tabungan sebesar Rp 93.357.350,-. Peningkatan tabungan masyarakat Kabupaten Jeneponto di tahun 2011,2012,2013 dan 2014 di sebabkan oleh inflasi yang menurun dan tingkat suku bunga lebih tinggi sehingga masyarakat kabupaten jeneponto mengurangi pengeluaranya untuk konsumsi guna untuk menambah tabungan mereka karena msayarakat Kabupaten Jeneponto mempunyai harapan bahwa uang mereka akan bertambah pada bulan berikutnya .Dan sebaliknya pada tahun 2015 terjadi penurunan tabungan masyarakat Kabupaten Jeneponto di karenakan terjadi inflasi meningkat dan suku bunga menurun sehingga masyarakat akan menambah permintaan terhadap barang konsumsi, jadi akan menyebabkan daya tabung masyarakat Kabupaten Jeneponto menurun .

Laju pertumbuhan produktivitas sektor industri di Kabupaten Jeneponto padatahun 2011-2015 . Laju pertumbuhan produktivitas sektor industri di Kabupaten Jeneponto di mana sektor pertanian dan sektor keuangan sewa dan jasa masih dominan dalam peningkatan PDRB di pada tahun 2011 yang paling banyak berkontribusi laju

pertumbuhan sektor industri yakni sektor industri pertanian sebesar 8,63 persen,sektor industri listrik gas dan air bersih sebesar 9,77 persen,dan sektor industri keuangan sewa dan jasa sebesar 10,28 persen sedangkan di tahun 2012 sektor industri pertanian mengalami penurunan laju pertumbuhan sebesar 8,19 persen,sektor industri listrik gas dan air bersih mengalami peningkatan sebesar 13,39 persen dan sektor industri keuangan sewa dan jasa mengalami peningkatan sebesar 12,89 persen selanjutnya di Tahun 2013 sektor industri pertanian mengalami penurunan laju pertumbuhan lagi sebesar 7,00 persen,sektor industri listrik gas dan air bersih mengalami penurunan sebesar 12,94 persen dan sektor industri keuangan sewa dan jasa mengalami penrunan sebesar 11,09 selanjutnya pada tahun 2014 sektor 
industry pertanian mengalami peninkatan laju pertumbuhan sebesar 8,45 persen,sektor industri listrik gas dan air bersih mengalami peningkatan sebesar 13.52 persen dan sector persen, sektor industri listrik gas dan air bersih mengalami penurunan sebesar 13,23 persen dan sektor industri keuangan sewa dan jasa mengalami penrunan sebesar 11,54 persen. Hal yang menyebabkan peningkatan laju pertumbuhan sektor industri pertanian bisa diakibatkan oleh perubahan iklim yang berpengaruh pada ketersediaan air untuk pengairan lahan pertanian yang kondisinya bagus, sedangkan di sektor listrik, gas dan air bersih mengalami peningkatan di sebabkan meningkatnya permintaan mayarakat kabupaten jeneponto terhadap listrik, gas dan air bersih, demikian halnya air bersih memberikan sumbangan kedua terbesar dalam membentuk PDRB sektor listrik Gas dan air, dan di sektor industri keuangan sewa dan jasa meningkat di sebabkan di bidang keuangan yakni pegadaian,pembiayaa,koperasi dan perbankan yang pertumbuhanya pesat , di mana masyarakat banyak menggunakan jasa perbankan,pegadaian,koperasi dan pembiayaan di Kabupaten Jeneponto.

Laju pertumbuhan produktivitas sektor jasa di Kabupaten Jeneponto pada tahun 2011 sektor jasa pengangkutan dan komunikasi sebesar 2,23 persen dimana pada tahun 2012 terjadi penurunan sebesar 2,21 persen,dan pada tahun 2013 sama halnya dengan tahun 2014 yang laju pertumbuhan sektor jasa pengangkutan dan komunikasi sama sebesar 2,22 persen terus di tahun 2015 terjadi penurunan lagi 2,21 persen. Sedangkan sektor jasa keuangan sewa dan jasa perusahaan di kabupaten jeneponto pada tahun 2011 ssebesar 5,07 persen dimana pada tahun 2012 terjadi peningkatan sebesar 5,19 persen,dan pada tahun 2013 sama industri keuangan sewa dan jasa mengalami peningkatan sebesar 11,99 .dan pada tahun 2015 sektor industri pertanian mengalami peningkatan laju pertumbuhan sebesar 8,62

halnya dengan tahun 2014 yang laju pertumbuhanya terjadi peningkatan sebesar 5,44 persen terus di tahun 2015 terjadi penurunan lagi sebesar 5,31. Jasa-jasa lainya di kabupaten jeneponto pada tahun 2011 sebesar 29,53 di mana pada tahun 2012 terjadi peningkatan 29,76 persen dan pada tahun 2013 sama halnya dengan tahun 2014 terjadi peningkatan sebesar 29,98 persen terus di tahun 2015 terjadi penurunan sebesar 29,87 persen. Hal yang menyebabkan terjadi penurunan pertumbuhan di sektor jasa kabupaten jeneponto di sebabkan oleh beberapa pelaku usaha sektor jasa di kabupaten jeneponto jalan di tempat dan tidak terlihatanya berbagai inovasi yang di lakukan sehingga berdampak pada pertumbuhan sektor jasa ,sedangkan peningkatan sektor jasa di kabupaten jenponto terjadi karena meningkatnya pertumbuhan sektor jasa darat, dan laut yang terkait dengan arus distribusi barang antarwilayah serta jasa keuangan,sewa,perusahaan jasa lainya terkait dengan Terjadinya peningkatan pendapatan masyarakat terutama kalangan menengah menyebabkan naiknya kemampuan menabung setiap tahun. Sejalan dengan itu lembaga keuangan menawarkan berbagai alternative simpanan yang memberikan fasilitas kemudahan penabung melakukan transaksi.

\section{Infrastruktur dan Sumber Daya Alam Kabupaten Jeneponto}

Ketersediaan dan Kualitas Sumber Daya Lahan.

Pada tahun 2015 ketersediaan dan kualitas sumber daya lahan Kabupaten Jeneponto memiliki potensi sumber daya lahan yang cukup besar diperuntukkan untuk kegiatan sosial dan kegiatan ekonomi masyarakat. Bila 
berdasarkan jenis penggunaan tanahnya (Land use) , maka pengunaan tanah yang terluas adalah Tegalan/Kebun yaitu seluas 34.154,14 ha atau $45,56 \%$ selanjutnya Persawahan seluas $20.014,08$ ha $(26,69 \%)$,

Hutan Negara seluas 9.842,65 ha $(13,12 \%)$, Permukiman seluas $4.892,27$ ha $(6,52 \%)$, Tambak seluas $1.624,95$ ha $(2,16 \%)$, Kolam/Empang seluas 748 ha $(0,99 \%)$, Perkebunan seluas 534,42 ha $(0,71 \%)$ dan penggunaan terkecil adalah ladang/huma seluas 313,63 ha $(0,42 \%)$ serta penggunaan lainnya seluas $2.854,85$ ha $(3,81 \%)$.

Pada tahun 2015 Sumber daya air di Kabupaten Jeneponto diperoleh dari air permukaan dan air tanah namun belum dikelola secara optimal sehingga ketersediaan air pada musim kemarau masih belum memenuhi kebutuhan mahluk hidup terutama manusia (masyarakat). Curah hujan di Kabupaten Jeneponto setiap tahunnya sangat rendah hanya \pm 87 hari hujan. Air hujan yang jatuh ke tanah hampir seluruhnya mengalir ke laut melalui sungai-sungai dan sangat kurang menjadi air tanah. Beberapa bendungan seperti bendungan Kelara, Tino dan Pokobulo yang sudah dimanfaatkan untuk mengairi sawah yang sumber airnya berasal dari sungai yang dibendung. Selain sungai yang sudah dibendung masih terdapat sungai potensial yang perlu penelitian lebih lanjut seperti sungai Tamanroya, sungai Allu, sungai Kelara dan sungai Marayoka di Kecamatan Bangkala.

Sumber daya air yang menjadi harapan Kabupaten Jeneponto adalah waduk Kelara Kareloe dan saat ini dalam tahap perencanaan pembangunan. Jika waduk ini terealisasi, maka akan berfungsi sebagai waduk multiguna (multipurpose dam), diantaranya dapat berfungsi sebagai sarana irigasi, pembangkit tenaga listrik, penyediaan air baku untuk air bersih dan pariwisata serta perikanan.

Pada tahun 2015 Meskipun sektor kehutanan memberikan kontribusi yang lebih kecil dibanding sektor pertanian terhadap PDRB Kabupaten Jeneponto yaitu hanya

$0,03 \%$, namun perannya tidak dapat diabaikan begitu saja karena sebagian besar hasil sektor kehutanan baik yang telah melalui proses pengolahan maupun tidak, merupakan komoditas ekspor seperti kayu dan hasil olahannya.

Kondisi hutan kabupaten Jeneponto cukup memprihatinkan karena mengalami penggundulan akibat kegiatan yang tidak bertanggung jawab sehingga fungsi hidrologisnya hilang. Pada saat musim hujan, aliran permukaan (run off) cukup besar yang dapat mengakibatkan erosi. Akibat dari erosi tersebut mengakibatkan terjadinya pendangkalan sungai dan bangunan serta saluran irigasi tidak berfungsi sebagaimana mestinya. Akibat lain yang ditimbulkan dari kondisi hutan yang gundul adalah rendahnya curah hujan dan punahnya berbagai margasatwa.

Pemerintah Kabupaten Jeneponto telah melakukan berbagai upaya untuk mengamankan kawasan hutan di daerah ini yang sebagian besar dalam kondisi kritis, antara lain, melalui program reboisasi dan penghijauan, penanaman Tanaman Hutan Rakyat (HR) dan penanggulangan kebakaran hutan, ternak liar dan peladang berpindah. luas hutan di Kabupaten Jeneponto adalah $9.446 \mathrm{Ha}$ dengan rincian: hutan lindung $9.189 \mathrm{Ha}$, hutan produksi terbatas $140 \mathrm{Ha}$ dan Hutan produksi tetap $117 \mathrm{Ha}$. kawasan hutan yang telah rehabilitasi kembali seluas 
1380 Ha. reboisasi yang berhasil dilakukan seluas 150 Ha atau mengalami penurunan sebesar 20,83\% yakni $720 \mathrm{Ha}$. Sedangkan program penghijauan yang berhasil dilakukan adalah $200 \mathrm{Ha}$.

\section{Sumber Daya Manusia}

Angka ketergantungan di kabupaten jeneponto di mana pada tahun 2011 Jumlah penduduk usia tidak produktif sebesar 126.298 sedangkan di tahun 2012 terjadi peningkatan sebesar 127.022 terus di tahun 2013 terjadi peningkatan juga sebesar selanjutnya di tahun 2014 terjadi peninngkatan sebesar 129.493 Dan di tahun 2015 terjadi penurunan jumlah penduduk usia tidak produktif 128.792.sedangkan jumlah penduduk usia 15-64 tahun pada tahun 2011 sebesar 219.851 selanjutnya di tahun 2012 terjadi peningkatan sebesar 221.116 terus di tahun 2013 terjadi peningkatan jumlah penduduk usia 1564 sebesar 223.794 dan di tahun 2015 terjadi penurunan sebesar 223.441. Hal yang menyebabkan angka ketergantungan di kabupaten jeneponto meningkat yakni terjadinya kegagalan dalam menurunkan angka fertilitas akan memperbesar proporsi penduduk non produktif dan penurunan angka ketergantungan di kabupaten jeneponto di sebabkan oleh adanya keseimbangan kualitas usia produktif. Menurunya angka ketergantungan dapat meningkatan perekenomian di suatu negara,inilah yang menjelaskan hubungan pertumbuhan penduduk dengan pertumbuhan ekonomi,di mana semakin tinggi pertumbuhan penduduk usia produktif maka berhubungan positif terhadap GDP per kapita.

Angkatan kerja di Kabupaten Jeneponto pada tahun 2015 Di mana golongan umur 15-19 angkatan kerja berjumlah 201 sedangkan golongan umur 20-24 angkatan kerja berjumlah 541 terus golongan umur 25-29 angkatan kerja berjumlah 328 selanjutnya golongan umur 30-34 angkatan kerja berjumlah 137 terus golongan umur 35-39 angkatan kerja berjumlah 179 selanjutnya golongan umur 40-44 berjumlah 119 dan golongan umur 45 ke atas berjumlah 19 yang jumlah keseluruhan sebesar 1.524.

Persentase angkatan kerja di kabupaten jeneponto tahun 2015 di mana perentase angkatan kerja laki-laki lebih besar yakni sebesar 28\% dibandingkan persentase angkatan kerja prempuan $26 \%$ yang jumlah total keseleruhan persentase angkatan kerja di kabupaten di tahun 2015 sebanyak $54 \%$.

Pertumbuhan penduduk yang setiap tahun terus meningkat harus menjadi perhatian pemerintah dalam perencaan pembangunan. Jumlah penduduk tersebut terbagi habis ke dalam 80.209 rumah tangga, dimana rata- rata jumlah anggota rumah tangga sebanyak 4 jiwa.Kecamatan Bangkala merupakan kecamatan dengan jumlah terbesar yaitu sebesar 51.081 jiwa. Sedangkan yang terkecil adalah Kecamatan Arungkeke, sebesar 18.680 jiwa kepadatan penduduk rata-rata di Jeneponto sebesar 468 jiwa per kilometer persegi.Pada tahun 2015 terdapat sebanyak 170.368 jiwa penduduk laki-laki dan 181.807 jiwa penduduk perempuan, dengan rasio jenis kelamin (sex ratio) 93,76, yang berarti bahwa diantara 100 perempuan terdapat 93 laki-laki.

Penduduk menurut kelompok umur menunjukkan bahwa penduduk pada usia kerja (15-64 tahun) lebih besar daripada penduduk di usia non produktif (0-14 tahun dan 65+). Relatif menurunnya usia non produktif mengindikasikan akan adanya 
perbaikan kondisi perekonomian masyarakat, mengingat penduduk usia produktif memiliki peluang yang lebih besar untuk bekerja dan menghasilkan pendapatan. Angka ketergantungan pada tahun 2015 sebesar 57 dengan kata lain dari 100 orang usia produktif menanggung 57 orang usia non produktif.

\section{DAFTAR PUSTAKA}

Frinces, Z. (2013). Membangun Ekonomi Daerah di Indonesia. Yogyakarta: MM STIE Mitra Indonesia. 